Research Article

\title{
The Impact of Nickel Mining on Soil Properties and Growth of Two Fast-Growing Tropical Trees Species
}

\author{
Ricksy Prematuri, ${ }^{1}$ Maman Turjaman, ${ }^{2}$ Takumi Sato, ${ }^{3}$ and Keitaro Tawaraya $\mathbb{D}^{3}$ \\ ${ }^{1}$ Research Centre for Bioresources and Biotechnology, IPB University, Bogor 16680, Indonesia \\ ${ }^{2}$ Forestry Research and Development Agency (FORDA), The Ministry of Environment and Forestry, Bogor 16680, Indonesia \\ ${ }^{3}$ Faculty of Agriculture, Yamagata University, Tsuruoka 997-8555, Japan \\ Correspondence should be addressed to Keitaro Tawaraya; tawaraya@tds1.tr.yamagata-u.ac.jp
}

Received 11 July 2020; Revised 20 October 2020; Accepted 24 October 2020; Published 5 November 2020

Academic Editor: Monika Marković

Copyright (C 2020 Ricksy Prematuri et al. This is an open access article distributed under the Creative Commons Attribution License, which permits unrestricted use, distribution, and reproduction in any medium, provided the original work is properly cited.

\begin{abstract}
Opencast nickel mining is common in natural forests of Indonesia. However, rehabilitation of postmining degraded land is difficult. We investigated the effect of opencast nickel mining on soil chemical properties and the growth of two fast-growing tropical tree species, Falcataria moluccana and Albizia saman. Soil was collected from post-nickel mining land and a nearby natural forest. Soil $\mathrm{pH}$, available phosphorus (P) concentration, total carbon (TC) and total nitrogen (TN) concentration, C/N ratio, cation exchange capacity (CEC), and exchangeable $\mathrm{K}, \mathrm{Na}, \mathrm{Mg}, \mathrm{Ca}, \mathrm{Fe}$, and $\mathrm{Ni}$ concentrations were determined. Falcataria moluccana and A. saman were then grown in the collected soils for 15 weeks in a greenhouse. Shoot height and shoot and root dry weights of the seedlings were measured. The post--nickel mining soils TN, TC, available P, CEC, and exchangeable Ca and Na concentrations decreased by $98 \%, 93 \%, 11 \%, 62 \%, 85 \%$, and $74 \%$, respectively, in comparison with the natural forest soils. The $\mathrm{pH}$ of postmining soil was higher than natural forest soil. Shoot dry weight of $F$. moluccana seedlings grown in postmining soil was significantly $(P<0.05)$ lower than that of seedlings grown in natural forest soil. However, there was no difference in shoot dry weight between $A$. saman seedlings grown in natural forest soil and postmining soil, as well as root dry weights of both species. The results indicate that opencast nickel mining decreased soil fertility, which subsequently inhibited the growth of $F$. moluccana and A. saman seedlings.
\end{abstract}

\section{Introduction}

Nickel is one of the most important mining products in the world. In Indonesia, nickel is produced from opencast mines. Opencast nickel mining is an intensive process that has a significant impact on tropical rainforests, affecting both indigenous vegetation and soil fertility. Mining activity belongs to the land exploitation with consequent loss of ecological function and services [1]. It results in wide environmental degradation of the mined area and tends to destroy terrestrial ecosystems. Furthermore, it results in the loss of structure and function of soil due to the removal of the top layer of soil, with subsequent reductions in biodiversity and socioeconomic impacts [2].
To reduce damage caused by nickel mining, land rehabilitation activities are required. Rehabilitation land after mining activity to a previous forested land condition can guarantee the services of these areas for economic and ecosystem purposes [3]. Land should become a productive forested area for the sustainability of social authorization [4]; however, this is not easy. Revegetation of forests needs time and takes decades [5]. Forests are the ecosystems that consist of community, interacting as a system between living organisms and the nonliving components of the environment. They have undergone successional changes, in many ways, which take years or decades [6]. Returning disturbed land to become a forested area is required to guarantee the continuation of economic and ecosystem services to the environment. 
Nickel mining mostly belongs to the geological of serpentinite regions. These are found contaminated with a tremendous amount of trace metals which include $\mathrm{Cr}, \mathrm{Ni}$, and associated metals $(\mathrm{Mg}, \mathrm{Pb}, \mathrm{Co}, \mathrm{Zn}$, etc.) with other elements [7]. Nickel mining also causes drastic changes to the physical and chemical characteristics of the land [8]. Mining activities can cause the release of toxic metals to the environment; damage to heritage; pollution; and acid mine drainage. In serpentinite soils regions, this condition results unfavorable for most plants and habitat development that house certain plant biodiversity and communities with many endemic species [9].

One rehabilitation strategy for degraded tropical lands is to plant fast-growing tropical trees. Such plantations may help to reduce the negative impacts of degraded lands and may contribute to the long-term livelihood of forest communities following mining. It is important to select fastgrowing tropical trees species for increasing the success rate of rehabilitation. Falcataria moluccana, also known as batay, is one of the most important fast-growing multipurpose tree species in Indonesia. It is intended for industrial forest plantations because F. moluccana plants are included in fastgrowing species and have high ability to grow on a different type of soil condition, favorable silvicultural characteristics, and marketable quality of wood for forestry industries [10]. This species can be used for pulp and paper, fuelwood, shade trees, and as a nitrogen supplier to soil [11]. Moreover, Falcataria moluccana plays an important role in both commercial and traditional farming systems that are commonly called as huma in Indonesia. The plant has been adopted and cultivated by the village people, such as integration into the development of traditional agroforestry in huma [12]. Albizia saman (Fabaceae), with the preferred common name as rain tree, is originally from Northern South America and has become naturalized in the tropics, grows in a wide range of climatic conditions, best in the lowlands from sea level to $300 \mathrm{~m}$ with rainfall $600-3000 \mathrm{~mm}$, and is mainly used on agroforestry system for silvopasture and crop shade [13]. Albizia saman is an important species, a multipurpose tree with potentialities as an alternative feed for animals [14]. It also produces variation in breast diameter, attractive wood color, and physical properties of wood, such as green density and volume shrinkage [15]. Albizia saman has a massive root system with an equally large canopy. Most roots of A saman expand horizontally, but many fibrous roots expand vertically [16]. Both species belong to the nitrogen-fixing trees commonly used for the revegetation of postmining land and for national programs of revegetation in Indonesia. The species of nitrogen-fixing trees are able to form symbioses with nodulating nitrogenfixing bacteria. Rehabilitation of postmining land takes place across a wide variety of climatic and edaphic conditions [17]. For example, soil chemical properties of post-nickel mining sites can be strongly influenced by the presence of vegetation or tree species. Before implementing rehabilitation in degraded mining lands, it is necessary to select tropical tree seedlings that are adapted to postmining soil.

The objective of this study was to determine the impact of opencast nickel mining on soil chemical properties and, subsequently, its effect on the growth of two fast-growing tropical tree species, F. moluccana and A. saman, under greenhouse conditions.

\section{Materials and Methods}

2.1. Soil Sampling. Soil samples were collected from the top layer at PT Vale Indonesia, a nickel mining site in Sorowako, East Luwu, South Sulawesi, Indonesia (Figure 1). PT Vale Indonesia, previously named PT International Nickel Indonesia (INCO), was founded in 1968. The company, currently, has mining concessions belonging to Wallace's line of almost 120.00 hectares, most of which are still in the form of natural forests. The samples were collected from 3 natural forest sites $\left(2^{\circ} 34^{\prime} 06^{\prime \prime} \mathrm{S}, \quad 121^{\circ} 20^{\prime} 52^{\prime \prime} \mathrm{E} ; \quad 2^{\circ} 34^{\prime} 20^{\prime \prime} \mathrm{S}, \quad 121^{\circ} 25^{\prime} 03^{\prime \prime} \mathrm{E}\right.$; $\quad$ and $\left.2^{\circ} 34^{\prime} 20^{\prime \prime} \mathrm{S}, 121^{\circ} 25^{\prime} 03^{\prime \prime} \mathrm{E}\right)$ and 3 post-nickel mining sites $\left(2^{\circ} 34^{\prime} 26^{\prime \prime} \mathrm{S}, \quad 121^{\circ} 21^{\prime} 37^{\prime \prime} \mathrm{E} ; 2^{\circ} 35^{\prime} 19^{\prime \prime} \mathrm{S}, \quad 121^{\circ} 22^{\prime} 30^{\prime \prime} \mathrm{E}\right.$; and $\left.2^{\circ} 31^{\prime} 36^{\prime \prime} \mathrm{S}, 121^{\circ} 29^{\prime} 47^{\prime \prime} \mathrm{E}\right)$ to characterize soil properties. Litter, roots, and stones were scraped away from the surface before soil samples were taken. The samples were collected using a hand scope and mixed thoroughly before being placed in a clean and seal plastic bag. Five soil samples were collected from each site at a depth of $0-25 \mathrm{~cm}$. A small subsample was taken and ground for chemical analysis. The remaining soil was kept for the plant growth experiment.

2.2. Analysis of Soil Properties. The soil was air-dried and passed through a $<2 \mathrm{~mm}$ sieve. Soil $\mathrm{pH}$ was analyzed through two ways: using $\mathrm{H}_{2} \mathrm{O}$ and using $\mathrm{KCl}$. Available phosphorus (P) [18] was extracted with $0.001 \mathrm{M}$ sulfuric acid and analyzed using the ammonium molybdate method. Total carbon (TC) and total nitrogen (TN) were analyzed using a C:N analyzer (Sumigraph NC-220F, Tokyo) [19]. Exchangeable potassium $(\mathrm{K})$, sodium $(\mathrm{Na})$, magnesium $(\mathrm{Mg})$, and calcium (Ca) were extracted with $1 \mathrm{M}(\mathrm{pH} 7)$ ammonium acetate analyzed using an atomic absorption spectrophotometer (Hitachi model Z-5000 series Polarized Zeeman, Tokyo) [19]. To determine cation exchange capacity (CEC), excess $\mathrm{NH}_{4}{ }^{+}$was removed, and an extraction was performed with $100 \mathrm{~g} \mathrm{~L}-1 \mathrm{KCl}$. The supernatant was analyzed using the semimicro Schöllenberger method [19].

2.3. Growth of Two Fast-Growing Tropical Tree Species. Two fast-growing tropical tree species, F. moluccana and A. saman, were selected for this study. Seeds of both tree species were purchased from a local company, Central Java, Indonesia. The seeds were soaked in water at $80^{\circ} \mathrm{C}$ for $2 \mathrm{~min}$. They were then pregerminated in plastic containers using zeolite as a germination medium. After radicle growth, individual plants were selected for sowing based on uniformity. Trees were grown in polyethylene pots (height: $7.5 \mathrm{~cm}$, diameter: $5 \mathrm{~cm}$ ) containing $200 \mathrm{~g}$ of soil. Each pot contained soil from a different soil sample, resulting in 30 pots, 15 with natural forest soil, and 15 with postmining soil. Two tree seedlings were transplanted for each soil sample, resulting in a total of 60 pots. Pots were positioned in a greenhouse in a randomized block design. The greenhouse was located in the Forest Microbiology Laboratory, Research 




Figure 1: The location of soil sample collection at PT Vale Indonesia, Sorowako, East Luwu, South Sulawesi, Indonesia.

and Development Agency (FORDA), the Ministry of Environment and Forestry, Bogor, West Java, Indonesia $\left(6^{\circ} 36^{\prime \prime} \mathrm{S}, 106^{\circ} 45^{\prime \prime} \mathrm{E}\right)$. The temperature varied between 25 and $37^{\circ} \mathrm{C}$, relative humidity was $80 \%-90 \%$, and the photoperiod was approximately $12 \mathrm{~h}$. The plants were grown for 15 weeks, and watering by deionized water was applied to maintain a moisture content similar to field capacity.

2.4. Harvest. Shoot height, measured $1 \mathrm{~cm}$ from the soil surface in the pot, was determined every 2-3 weeks. After 15 weeks, the shoots were harvested and oven-dried at $70^{\circ} \mathrm{C}$ for $72 \mathrm{~h}$ before dry weight was recorded.

2.5. Statistical Analysis. Data on laboratory tests of soil chemical properties and plant growth were analyzed using a statistical test, Student's $t$-test at $95 \%$ confidence interval $(P<0.05)$ in Minitab (Minitab Inc., USA). When the $F$ value was significant, the least significant difference (LSD) was calculated to compare treatment means.

\section{Results and Discussion}

3.1. Impact of Nickel Mining on Soil Chemical Properties. We found that the chemical properties of post-nickel mine soil differed significantly from nearby natural forest soil (Table 1). Total N, TC, available $\mathrm{P}, \mathrm{CEC}$, exchangeable $\mathrm{Ca}$, and $\mathrm{Na}$ were lower in post-nickel mine soil than natural forest soil. Conversely, soil $\mathrm{pH}$ and $\mathrm{C} / \mathrm{N}$ ratio were higher in post-nickel mine soil than natural forest soil. There were no differences in $\mathrm{Mg}, \mathrm{K}, \mathrm{Fe}$, and $\mathrm{Ni}$ between natural forest soil and post-nickel mine soil.

Opencast nickel mining activities have an impact on soil fertility. In opencast mining, rock or minerals are extracted from an open pit or burrow. Topsoil and vegetation are seriously damaged during opencast nickel mining, thus decreasing soil fertility. Nickel ultramafic soils are commonly known as serpentines in the botanical and ecological literature [9]. The serpentinized and ultramafic soil/rock are distinguished by high levels concentration of heavy metals and unbalanced $\mathrm{Ca} / \mathrm{Mg}$ ratio [7] and poor plant nutrient content such as N, P, and K [9]. Nitrogen and phosphorous are the most important nutrients for soil productivity and plant development. It significantly enhances plant growth and productivity, chlorophyll and carotene contents, and promotes root morphology [20]. Most studies have demonstrated the influence of nitrogen enrichment on plant communities. Soils are known to have heterogeneous physical, chemical, and biological properties. Soil heterogeneity is closely related to nitrogen enrichment to determine plant growth and nutrient status [21]. The availability of $\mathrm{N}$ in the soil directly influences a wide range of ecological processes, both above and below ground, at the physiological, community, environment, ecosystem services, and global levels [22]. In our study, we found that post-nickel mine soil had $98 \%$ less TN than a nearby natural forest soil. This indicates a greater decline in TN compared with gold mine tailings in Indonesia (91.3\%) [23], an opencast bauxite mine in Bintan Island, Indonesia (75\% reduction) [24], and 
TABle 1: Chemical properties of soils from natural forest and post-nickel mining land. Different letters within row indicate significant difference $(P<0.05)$ by $t$-test. Mean \pm standard error are shown $(n=15)$.

\begin{tabular}{|c|c|c|c|c|c|}
\hline \multirow{2}{*}{$\begin{array}{l}\text { Chemical properties } \\
\mathrm{pH}\left(\mathrm{H}_{2} \mathrm{O}\right)\end{array}$} & \multicolumn{2}{|c|}{ Natural forest } & \multicolumn{2}{|c|}{ Postmining land } & \multirow{2}{*}{$\begin{array}{c}\text { Change (\%) } \\
+1.29(26)\end{array}$} \\
\hline & $5.02 \pm 0.10$ & $\mathrm{~b}$ & $6.31 \pm 0.05$ & $\mathrm{a}$ & \\
\hline $\mathrm{pH}(\mathrm{KCl})$ & $4.66 \pm 0.10$ & $\mathrm{~b}$ & $6.31 \pm 0.07$ & $\mathrm{a}$ & $+1.65(35)$ \\
\hline Total carbon $(\mathrm{g} / \mathrm{kg})$ & $40.20 \pm 0.25$ & $\mathrm{a}$ & $2.90 \pm 0.05$ & $\mathrm{~b}$ & $-37.30(93)$ \\
\hline Total nitrogen $(\mathrm{g} / \mathrm{kg})$ & $2.60 \pm 0.02$ & $\mathrm{a}$ & $0.057 \pm 0.01$ & $\mathrm{~b}$ & $-2.54(98)$ \\
\hline $\mathrm{C} / \mathrm{N}$ (ratio) & $15.84 \pm 0.29$ & $\mathrm{~b}$ & $65.12 \pm 8.72$ & $\mathrm{a}$ & $+49.28(311)$ \\
\hline Available $\mathrm{P}\left(\mathrm{mg} \mathrm{P}_{2} \mathrm{O}_{5} / \mathrm{kg}\right)$ & $12.30 \pm 0.02$ & $\mathrm{a}$ & $11.00 \pm 0.02$ & $\mathrm{~b}$ & $-1.30(11)$ \\
\hline $\operatorname{CEC}\left(\mathrm{cmol} \mathrm{kg}^{-1}\right)$ & $8.23 \pm 0.67$ & $\mathrm{a}$ & $3.15 \pm 0.71$ & $\mathrm{~b}$ & $-5.08(62)$ \\
\hline $\mathrm{Ca}(\mathrm{mg} / \mathrm{kg})$ & $5.85 \pm 0.93$ & $\mathrm{a}$ & $0.86 \pm 0.29$ & $\mathrm{~b}$ & $-4.99(85)$ \\
\hline $\mathrm{Mg}(\mathrm{mg} / \mathrm{kg})$ & $7.32 \pm 0.81$ & $\mathrm{a}$ & $6.27 \pm 1.18$ & $\mathrm{a}$ & $-1.05(14)$ \\
\hline $\mathrm{K}(\mathrm{mg} / \mathrm{kg})$ & $10.84 \pm 6.23$ & $\mathrm{a}$ & $5.25 \pm 5.25$ & $\mathrm{a}$ & $-5.59(52)$ \\
\hline $\mathrm{Na}(\mathrm{mg} / \mathrm{kg})$ & $0.81 \pm 0.19$ & $\mathrm{a}$ & $0.21 \pm 0.08$ & $\mathrm{~b}$ & $-0.6(74)$ \\
\hline $\mathrm{Fe}(\mathrm{mg} / \mathrm{kg})$ & $2.12 \pm 0.09$ & $\mathrm{a}$ & $38.30 \pm 18.73$ & $\mathrm{a}$ & +36.18 (1707) \\
\hline $\mathrm{Ni}(\mathrm{mg} / \mathrm{kg})$ & $3.30 \pm 0.33$ & $\mathrm{a}$ & $3.17 \pm 0.45$ & $\mathrm{a}$ & $-0.13(4)$ \\
\hline
\end{tabular}

an opencast coal mine in India (53\% reduction in $\mathrm{TN})$ [25] and USA (53\%-80\% reduction) [26].

Phosphorus is another essential plant macronutrient. In the present study, the available $\mathrm{P}$ of post-nickel mine soil was $11.00 \pm 0.02 \mathrm{mg} \mathrm{P}_{2} \mathrm{O}_{5} / \mathrm{kg}$, which was lower than that in natural forest soil $\left(12.30 \pm 0.02 \mathrm{mg} \mathrm{P}_{2} \mathrm{O}_{5} / \mathrm{kg}\right)$. Soil phosphorus is the element considered important in determining the biodiversity and biomass of natural ecosystems [27]. Production of many ecosystems especially in subtropical and tropical regions is strongly considered to be $\mathrm{P}$ rather than $\mathrm{N}$ limited [28]. Recent literature indicates that in tropical forests, a large fraction of $\mathrm{P}$ is found as organic and microbial $\mathrm{P}$ in the soil; plant adaptations to absorb organic $\mathrm{P}$, including the phosphatase enzymes. Plants also cope with low $\mathrm{P}$ availability in the soil through enhancements in $\mathrm{P}$ use-efficiency resulting from increased retention time of $\mathrm{P}$ in biomass and decreased tissue P concentration [29].

The impact of surface mine activity involves drastic disturbances to the ecosystem and soil properties including the reduction of soil organic material (SOM) and organic carbon [30]. Soil organic matter is lost as a result of the initial stripping of the soil from the site. Further losses occur while the soil is stored in stockpiles during replacement to the reclaimed site. This has serious implications because SOM plays an important role such as in soil fertility and water holding capacity. Soil is the primary store of terrestrial carbon [31]. Topsoil management plays an important role that rehabilitation of postmining land leads to prevention of carbon losses. Soils' surfaces after reclamation of post-coal mines in Wyoming are sequestering $\mathrm{C}$ at a rapid rate. For example, soil organic $\mathrm{C}$ content at one reclaimed mine site near Hanna, WY, USA, increased from $10.9 \mathrm{~g} \mathrm{C} \mathrm{kg}^{-1}$ in 1983 to $20.5 \mathrm{~g} \mathrm{C} \mathrm{kg}^{-1}$ in 2002 [32]. Carbon is an important soil parameter; it improves soil physical and chemical properties and overall soil quality. Soil carbon exists in various forms that are functionally different and have contrasting residence times. Removal of topsoil from mining sites and subsequent replacement and mixing with underlying soil considerably reduces the concentration of soil organic $C$. In the current study, we found that TC was $93 \%$ lower in post-nickel mine soil compared to natural forest soil, with concentrations of
$2.90 \pm 0.05 \mathrm{~g} / \mathrm{kg}$ and $40.20 \pm 0.25 \mathrm{~g} / \mathrm{kg}$, respectively. This decline in TC is greater than that of oil palm plantations, in which TC can decline by $42 \%$ [33].

Soil $\mathrm{pH}$ was higher in post-mine soil compared with natural forest soil, by $26 \%$ for the $\mathrm{H}_{2} \mathrm{O}$ method and by $35 \%$ for the $\mathrm{KCl}$ method. This happens because of the loss of vegetation cover on the top layer of soil on postmining land. Most postmining land is categorized as dry land which contains metals such as $\mathrm{Mg}, \mathrm{Na}, \mathrm{K}$, and $\mathrm{Ca}$ which are very high in soil $\mathrm{pH}$ of 9.0 [34]. In their natural forest environment, however, soil chemicals such as $\mathrm{Mg}, \mathrm{Na}, \mathrm{Ca}, \mathrm{K}$, and other chemical characteristics produced from the decomposition process of organic soil material will be absorbed by the plants. It results in the conservation and efficiency of the nutrient with a closed ecological nutrient cycle $[35,36]$. The higher $\mathrm{pH}$ of postmining soil could support mining rehabilitation activities. Soil $\mathrm{pH}$ is influenced by various soil biological, chemical, and physical properties that affect the growth of plants and biomass yield [37]. For example, many $\mathrm{N}$ and $\mathrm{C}$ mineralization processes occur at a $\mathrm{pH}$ between 6.5 and 8 . The application of dolomite may be considered to increase soil $\mathrm{pH}$ even further. It can also increase many other soil nutrients, including $\mathrm{Mg}$ [38].

Soil cation exchange capacity (CEC) is a major soil chemical property. It reflects the surface properties of soil colloids, and the retention and supply proportions of soil fertilizer. Cation exchange capacity is a key indicator for evaluating soil fertility, plant growth, and pollutants partition and transport in soils. It is also an important parameter that influences the adsorption of heavy metals and organic pollutants in soils [39]. We found that CEC in the present study was $62 \%$ lower in post-nickel mining, in comparison with natural forest soil. The decrease in CEC is greater compared to post-bauxite mining [24] and is lower compared to gold tailings [23], in which CEC can decrease by $30 \%$ and $76 \%$, respectively. Some of the important micronutrients that are essential for plant growth are $\mathrm{Ni}$ and $\mathrm{Fe}$. The micronutrient is available in the soil due to the continuous weathering of minerals mixed with primary minerals. Nickel contributes to the nitrogen fixation in legume plants and is the component of the urease enzyme which 
brings about hydrolysis of urea [40], while $\mathrm{Fe}$ is a major micronutrient for almost all living organisms which plays important role in metabolic processes such as photosynthesis, DNA synthesis, and respiration. Furthermore, many metabolic pathways are stimulated by $\mathrm{Fe}$, and it is a prosthetic group constituent of many enzymes [41]. In high-level concentration, however, $\mathrm{Fe}$ is toxic. It can act catalytically through the Fenton reaction to generate hydroxyl radicals, which can destroy proteins, lipids, and DNA. Consequently, plants must respond to $\mathrm{Fe}$ stress because of both $\mathrm{Fe}$ deficiency and Fe overload [41]. In the current study, we found that Fe was $1707 \%$ tending to higher in post-nickel mine soil compared to natural forest soil, with concentrations of $38.30 \pm 18.73 \mathrm{mg} / \mathrm{kg}$ and $2.12 \pm 0.09 \mathrm{mg} / \mathrm{kg}$, respectively.

3.2. Growth of Fast-Growing Tropical Tree Species. The shoot height of $F$. moluccana seedlings grown in both the natural forest soil and post-nickel mine soil increased from 2 to 15 weeks after planting (Figure 2). In comparison with natural forest soil, shoot height at 10,13, and 15 weeks after planting was significantly lower in post-nickel mine soil. No significant difference in shoot height was shown between natural forest and post-nickel mine soil at 2, 4, 6, and 8 weeks after planting. The shoot dry weight of $F$. moluccana grown in post-nickel mine soil was significantly $(P<0.05)$ lower than that of natural forest soil (Figure 3). Root dry weight of F. moluccana grown in natural forest soil was generally higher in comparison with post-nickel mine soil without statistical significance. The shoot height of $A$. saman seedlings of natural forest and post-nickel mine soil increased from 2 to 15 weeks after planting (Figure 4). Shoot height 15 weeks after planting was significantly lower in the postnickel mine soil than that in the natural forest soil. Shoot dry weight in natural forest soil was generally higher than that in post-nickel mine soil (Figure 5), while root dry weight in post-nickel mine soil was generally higher than that in natural forest soil without statistically significance.

The rehabilitation of land after nickel mining is a mandatory activity for all mining companies in Indonesia. One rehabilitation approach is to plant fast-growing tropical leguminous trees that have a high level of adaptation and survival on post-nickel mining land and improve the fertility of the soil. Our results, as show in Figure 5, suggest that A. saman is more tolerant to growth on post-nickel mining land than F. moluccana. Albizia saman is a fast-growing tropical leguminous tree that is highly adapted to various types of soil with a wide $\mathrm{pH}$ range and poor drainage [16]. Planting leguminous trees that can grow on post-nickel mining land can improve the ability of the soil to retain water. Large pores in the surface layer of natural forest soils (due to the activity of microbes and roots) allow infiltration of rainwater into the soil. In post-nickel mining land with low nitrogen concentration, the leguminous trees as nitrogen-fixing species could be used for revegetation. Several studies on revegetation of postmining land in Africa have shown that leguminous tree species have a high survival rate [42]. The successful use of leguminous trees for postmining land reclamation has also been demonstrated in Brazil.



FIGURE 2: Mean shoot height of Falcataria moluccana grown in soil from post-nickel mining land and natural forest for 15 weeks under greenhouse condition. Different letters indicate significant differences $(P=0.05)$. Error bars indicate standard error $(n=15)$.

Leguminous trees form a symbiosis with nodulating $\mathrm{N}$-fixing bacteria [43]. Several leguminous trees, including Caesalpinia sappan L., Enterolobium cyclocarpum (Jacq.) Griseb., Gliricidia sepium (Jacq.) Walp., Delonix regia (Hook.) Raf., and Cassia siamea Lamk., have been used in the rehabilitation of a former tin mining area in Bangka Island, Indonesia [44].

The use of organic amendments and microbial inoculants could increase soil fertility and help plant growth in post-nickel mine soil. For example, chicken manure, cow manure, mulch, municipal green waste, and litter compost might increase the success of rehabilitation. The application of chicken manure to post-coal mining land in Indonesia, which had very low soil nutrient concentrations, increased the growth of Samanea saman [45]. The treatment of municipal green waste had growth rates comparable to untreated plants for mine site rehabilitation. The use of municipal green waste on degraded opencast coal land in South East Wales, the United Kingdom, had significantly greater survival rates, compared with trees planted without green waste [46]. Other studies have shown that the addition of compost not only increases soil fertility and plant biomass but also reduces the concentration of trace elements in plant species grown in metal-contaminated mine soils [47]. Oyebamiji et al. [48] reported the distribution of heavy metal such as, $\mathrm{Pb}, \mathrm{Zn}, \mathrm{Cu}, \mathrm{Ni}, \mathrm{Cr}$, and $\mathrm{Fe}$ in active mining soils in southwestern Nigeria. Incorporation of compost provides benefits for remediating trace elements $(\mathrm{Cu}, \mathrm{Pb}, \mathrm{Zn}$, and $\mathrm{As})$ in polluted soil [49]. The dissolution of organic matter can increase the solubility of $\mathrm{Al}, \mathrm{Fe}$, and $\mathrm{Pb}$ within the reclaimed soils [50]. The application of microbial inoculants, such as arbuscular mycorrhizal fungi (AMF), could improve the growth and survival of trees on post-nickel mining land. Plants are part of the ecosystem with many and diverse microorganisms in the soil. It has been established that some 


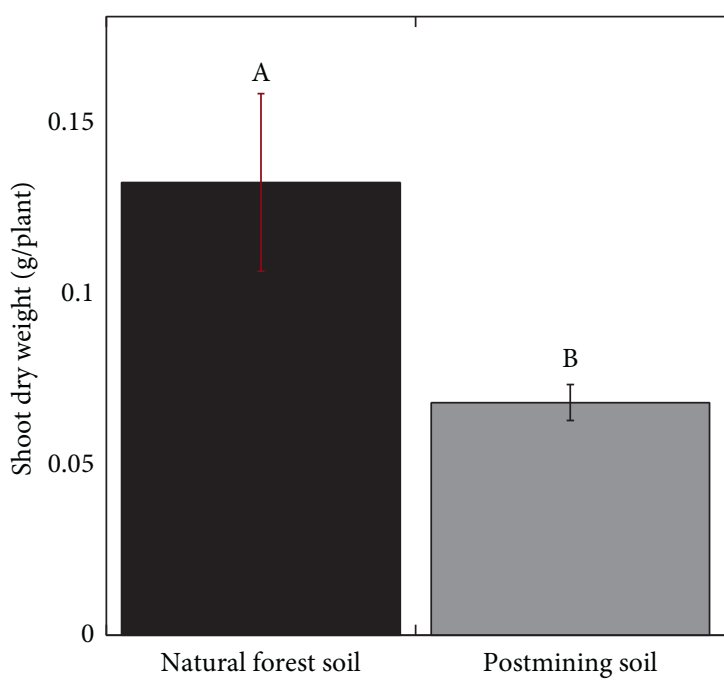

(a)



(b)

Figure 3: Mean shoot (a) and root (b) dry weight of Falcataria moluccana 15 weeks after planting in soil from post-nickel mining land and natural forest. Different letters indicate significant differences $(P=0.05)$. Error bars indicate standard error $(n=15)$.

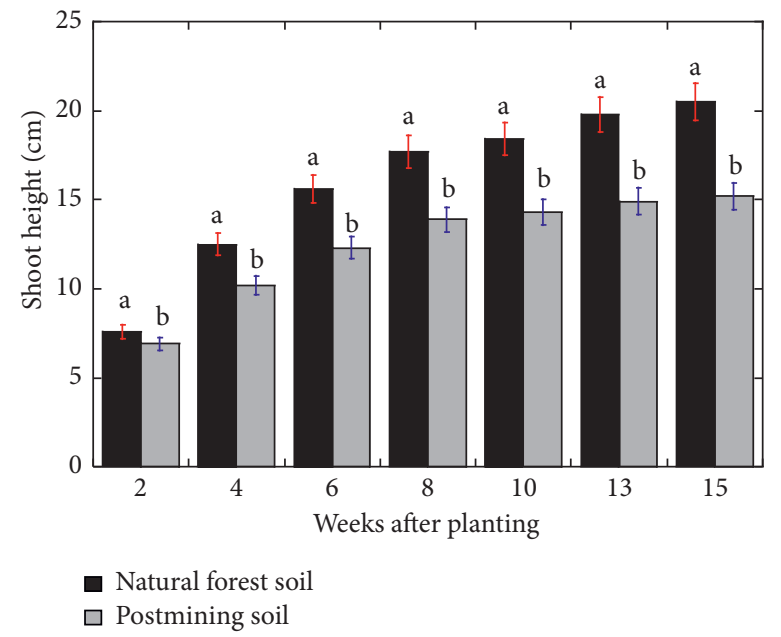

FIgURE 4: Mean shoot height of Albizia saman grown in soil from post-nickel mining land and natural forest for 15 weeks under greenhouse condition. Different letters indicate significant differences $(P=0.05)$. Error bars indicate standard error $(n=15)$.

of these microbes, such as mycorrhizal fungi or nitrogenfixing bacteria, play important roles in plant development by improving mineral nutrition [51]. Several investigations have shown good results; the application of AMF increased the growth and survival of $P$. falcataria and A. saman in post-coal mining land in Indonesia [52]. Additionally, the use of coconut powder inoculated with AMF increased the survival of Anadenanthera colubrina seedlings in postmining soil in Brazil [53]. The application of AMF and leguminous trees might be used to increase the success of revegetation programs in post-nickel mining land. In our study, Fe content in postmining soil was seventeen times higher than that in natural forest soil. Agus et al. [54] reported that revegetation with fast-growing legume species of Pongamia pinnata and AMF application can not only increase nutrient contents of post-coal mining soil but also increases Fe absorption, which is mostly accumulated in the root system.

Fast-growing tropical leguminous trees that belong to the $\mathrm{N}$-fixing species may contribute to improving soil quality on degraded soil of post-nickel mining land. Some results indicate that legumes plant may increase the resistances of soil physicochemical and biological properties to the ecosystem disturbance [55]. Legumes fix the atmospheric nitrogen, release in the soil high-quality organic matter, and facilitate soil nutrients' circulation and water retention [56]. It could be investigated in future studies, in which fastgrowing tropical leguminous trees of F. moluccana or Albizia saman have a better impact to increase soil quality on post-nickel mining land. 


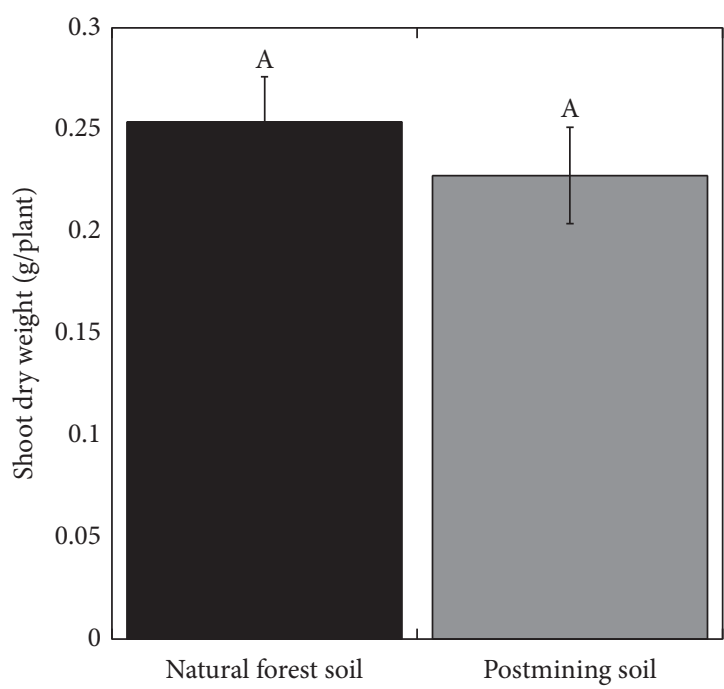

(a)



(b)

Figure 5: Mean shoot (a) and root (b) dry weight of Albizia saman 15 weeks after planting in soil from post-nickel mining land and natural forest. Different letters indicate significant differences $(P=0.05)$. Error bars indicate standard error $(n=15)$.

\section{Conclusions}

Opencast nickel mining impacted soil fertility. Total N, TC, available $\mathrm{P}$, and exchangeable $\mathrm{Ca}$ and $\mathrm{Na}$ concentrations of post-nickel mine soil were $98 \%, 93 \%, 11 \%, 85 \%$, and $74 \%$ lower than natural forest soil, respectively. The reduced fertility of postmining soil resulted in lower growth of the fast-growing tropical tree species F. moluccana and A. saman. However, our results suggest that $A$. saman was better adapted to growth on post-nickel mining land. There was no significant difference in biomass between A. saman on post-nickel mining soil and natural forest soil. In future studies, the comparison between F. moluccana and A. saman could be investigated to have a better impact on soil improvement on post-nickel mining land.

\section{Data Availability}

The data used for this study are available from the corresponding author upon request.

\section{Conflicts of Interest}

The authors declare that there are no conflicts of interest regarding the publication of this paper.

\section{Acknowledgments}

The authors would like to thank JSPS Ronpaku (Japan) for supporting this research. They are also grateful to Mr. Aris P. Ambodo from PT Vale Indonesia, Mrs. Ratna Irdiastuti and Mrs. Desi Maryanti from PT Performa Qualita Mandiri, Bogor, Indonesia, Mr. Hendro Guntoro from PT Green Planet Indonesia, Jakarta, Indonesia, and Ms. Noor F. Mardatin from IPB University, Bogor, Indonesia.

\section{References}

[1] M. Mentis, "Environmental rehabilitation of damaged land," Forest Ecosystems, vol. 7, no. 19, pp. 1-16, 2020.

[2] R. J. Lad and J. S. Samant, "Impact of bauxite mining on soil: a case study of bauxite mines at Udgiri, Dist-Kolhapur, Maharashtra state, India," International Research Journal of Environmental Sciences, vol. 4, no. 2, pp. 77-83, 2015.

[3] J. M. Metsaranta, S. Beauchemin, S. Langley, B. Tisch, and P. Dale, "Assessing the long-term ecosystem productivity benefits and potential impacts of forests re-established on a mine tailings site," Forests, vol. 9, no. 11, pp. 1-23, 2018.

[4] K. Moffat, J. Lacey, A. Zhang, and S. Leipold, "The social licence to operate: a critical review," Forestry, vol. 89, no. 5, pp. $477-488,2016$.

[5] S. E. Macdonald, S. M. Landhäusser, J. Skousen et al., "Forest restoration following surface mining disturbance: challenges and solutions," New Forests, vol. 46, no. 5-6, pp. 703-732, 2015.

[6] A. R. Taylor and H. Y. H. Chen, "Multiple successional pathways of boreal forest stands in central Canada," Ecography, vol. 34, no. 2, pp. 208-219, 2011.

[7] A. Kumar and S. K. Maiti, "Availability of chromium, nickel and other associated heavy metals of ultramafic and serpentine soil/rock and in plants," International Journal of Emerging Technology and Advanced Engineering, vol. 3, no. 2, pp. 256-268, 2013.

[8] N. V. W. Prasad, C. Nakbanpote, D. Phadermrod, and S. Rose, "Chapter 13-Mulberry and Vetiver for Phytostabilization of Mine Overburden: Cogeneration of Economic Products," Bioremediation and Bio Economy, pp. 295-328, Elsevier, London, UK, 2016.

[9] A. Chiarucci and A. J. M. Baker, "Advances in the ecology of serpentine soils," Plant and Soil, vol. 293, no. 1-2, pp. 1-2, 2007.

[10] H. Krisnawati, E. Varis, M. Kallio, and M. Kanninen, Paraserianthes falcataria (L.) Nielsen: Ecology, Silviculture and Productivity, Center for International Forestry Research, Bogor, Indonesia, 2011. 
[11] V. Yuskianti and S. Shiraishi, "Developing SNP markers and DNA typing using multiplexed single nucleotide primer extension (SNuPE) in Paraserianthes falcataria," Breeding Science, vol. 60, no. 1, pp. 87-92, 2010.

[12] J. Iskandar, B. S. Iskandar, and R. Partasasmita, "Introduction of Paraserianthes falcataria in the traditional agroforestry "huma" in Karangwangi village, Cianjur, West Java, Indonesia," Biodiversitass, Journal of Biological Diversity, vol. 18, no. 1, pp. 295-303, 2017.

[13] G. W. Staples and C. R. Elevitch, "Samanea Saman (Rain Tree)," Species Profiles for Pacific Island Agroforestry, http:// www.traditionaltree.org/, 2006.

[14] D. C. Delgado, R. Hera, J. Cairo, and Y. Orta, "Samanea saman, a multi-purpose tree with potentialities as alternative feed for animals of productive interest," Cuban Journal of Agricultural Science, vol. 48, no. 3, pp. 205-212, 2014.

[15] M. F. Obando and R. Moya, "Silviculture conditions and wood properties of Samanea saman and Enterolobium cyclocarpum in 19-year-old mixed plantations," Forest Systems, vol. 22, no. 1, pp. 58-70, 2013.

[16] M. Z. Haq, M. Robbani, M. Ali et al., "Damage and management of cyclone sidr-affected homestead tree plantations: a case study from Patuakhali, Bangladesh," Natural Hazards, vol. 64, no. 2, pp. 1305-1322, 2012.

[17] M. van Breugel, J. S. Hall, D. J. Craven et al., "Early growth and survival of 49 tropical tree species across sites differing in soil fertility and rainfall in Panama," Forest Ecology and Management, vol. 261, no. 10, pp. 1580-1589, 2011.

[18] E. Truog, "The determination of the readily available phosphorus of soils 1," Agronomy Journal, vol. 22, no. 10, pp. 874-882, 1930.

[19] A. L. Page, R. H. Miller, and S. R. Heeney, Methods of Soil Analysis-Part 2: Chemical and Microbiological Properties, American Society of Agronomy, Madison, WI, USA, 1982.

[20] M. Razaq, P. Zhang, H. I. Shen, and Salahuddin, "Influence of nitrogen and phosphorous on the growth and root morphology of Acer mono," PLoS One, vol. 12, no. 2, Article ID e0171321, 2017.

[21] P. G. Palacios, F. T. Maestre, R. D. Bardgett, and H. de Kroom, "Plant responses to soil heterogeneity and global environmental change," Journal of Ecology, vol. 100, no. 6, pp. 1303-1314, 2012.

[22] D. A. Frank and P. M. Groffman, Plant Rhizospheric N Processes: What We Don't Know and Why We Should Care, Biological Research Labs, Syracuse University Cary Institute of Ecosystem Studies, Syracuse, NY, USA, 2009.

[23] R. Prematuri, M. Turjaman, T. Sato, and K. Tawaraya, "Chemical characteristic of forest soil and gold mine tailings and their effect to the plant growth of two leguminous trees," International Journal of Plant \& Soil Science, vol. 32, no. 2, pp. 11-20, 2020.

[24] R. Prematuri, M. Turjaman, T. Sato, and K. Tawaraya, "Post bauxite mining land soil characteristics and its effects on the growth of Falcataria moluccana (Miq.) Barneby \& J.W. Grimes and Albizia saman (Jacq.), Merr," Applied and Environmental Soil Science, vol. 2020, Article ID 6764380, 8 pages, 2020.

[25] R. S. Singh, N. Tripathi, and S. K. Chaulya, "Ecological study of revegetated coal mine spoil of an Indian dry tropical ecosystem along an age gradient," Biodegradation, vol. 23, no. 6, pp. 837-849, 2012.

[26] R. K. Shrestha and R. Lal, "Changes in physical and chemical properties of soil after surface mining and reclamation," Geoderma, vol. 161, no. 3-4, pp. 168-176, 2010.
[27] M. D. Cramer, "Phosphate as a limiting resource: introduction," Plant and Soil, vol. 334, no. 1, pp. 1-10, 2010.

[28] P. M. Vitousek, S. Porder, B. Z. Houlton, and O. A. Chadwick, "Terrestrial phosphorus limitation: mechanisms, implications, and nitrogen-phosphorus interactions," Ecological Applications, vol. 20, no. 1, pp. 5-15, 2010.

[29] J. W. Dalling, K. Heineman, O. R. Lopez, S. J. Wtight, and B. L. Turner, "Nutrient availability in tropical rain forests: the paradigm of phosphorus limitation," in Tropical Tree Physiology: Adaptations and Responses in a Changing Environment, G. Goldstein and L. S. Santiago, Eds., vol. 6, pp. 261-273, Springer, Berlin, Germany, 2016.

[30] X. Liu, Z. Bai, W. Zhou, Y. Cao, and G. Zhang, "Changes in soil properties in the soil profile after mining and reclamation in an opencast coal mine on the Loess Plateau, China," Ecological Engineering, vol. 98, pp. 228-239, 2016.

[31] M. Tibbett, "Litter and carbon accumulation in soil after forest restoration: the Australian experience after bauxite mining," in Proceedings of the 19th World Congress of Soil Science, Soil Solutions for a Changing World, Brisbane, Australia, August 2010.

[32] P. D. Stahl, J. D. Anderson, J. L. Ingram, G. E. Schuman, and D. L. Mummey, "Accumulation of organic carbon in reclaimed coal mine soils of Wyoming," in National Meeting of the American Society of Mining and Reclamation and The 9th Billings Land Reclamation Symposium, Billings, MT, USA, June 2003.

[33] N. Rahman, A. de Neergaard, J. Magid, G. W. J. Van de Ven, K. E. Giller, and T. B. Bruun, "Changes in soil organic carbon stocks after conversion from forest to oil palm plantations in Malaysian Borneo," Environmental Research Letters, vol. 13, no. 10, Article ID 105001, 2018.

[34] B. Wasis and A. Andika, "Growth response of mahagony seedling (Swietenia macrophylla King) to addition of coconut shell charcoal and compost on ex-sand mining site of West Jawa Province in Indonesia," Archives of Agriculture and Environmental Science, vol. 2, no. 3, pp. 238-243, 2017.

[35] S. Barot, A. Ugolini, and F. B. Brikci, "Nutrient cycling efficiency explains the long-term effect of ecosystem engineers on primary production," Functional Ecology, vol. 21, pp. 1-10, 2007.

[36] B. Wasis, Arifin, and B. Winata, "Impact of bauxite mine to natural forest biomass and soil properties in Kas Island, Riau Island Province in Indonesia," Archives of Agriculture and Environmental Science, vol. 3, no. 3, pp. 264-269, 2018.

[37] D. Neina, "The role of soil $\mathrm{pH}$ in plant nutrition and soil remediation," Applied and Environmental Soil Science, vol. 2019, Article ID 5794869, 9 pages, 2019.

[38] M. Pawlikowski and D. Kozień, "Mineral supplements of soils," Open Access Journal of Environmental and Soil Sciences, Lupine Publishers, vol. 2, no. 4, New York, NY, USA, , Article ID 000145, 2019.

[39] D. Yunan, Q. Xianliang, and W. Xiaochen, "Study on cation exchange capacity of agricultural soils," IOP Conference Series: Materials Science and Engineering, vol. 392, Article ID 042039, 2018.

[40] I. V. Seregin and A. D. Kozhevnikova, "Physiological role of nickel and its toxic effects on higher plants," Russian Journal of Plant Physiology, vol. 53, no. 2, pp. 257-277, 2006.

[41] G. R. Rout and S. Sahoo, "Role of iron in plant growth and metabolism," Reviews in Agricultural Science, vol. 3, pp. 1-24, 2015.

[42] E. S. Festin, M. Tigabu, M. N. Chileshe, S. Syampungani, and P. C. Odén, "Progresses in restoration of post-mining 
landscape in Africa," Journal of Forestry Research, vol. 30, no. 2, pp. 381-396, 2019.

[43] G. M. Chaer, A. S. Resende, E. F. C. Campello, S. M. de Faria, and R. M. Boddey, "Nitrogen-fixing legume tree species for the reclamation of severely degraded lands in Brazil," Tree Physiology, vol. 31, no. 2, pp. 139-149, 2011.

[44] B. H. Narendra and Pratiwi, "Adaptability of some legume trees on quartz tailings of a former tin mining area in Bangka Island, Indonesia," Journal of Degraded and Mining Lands Management, vol. 4, no. 1, pp. 671-674, 2016.

[45] S. Darma, W. Kustiawan, D. Ruhiyat, and Sumaryono, "Organic fertilizers improves trembesi (Samanea saman) seedling growth, a case study of the implementation of postmining land reclamation and revegetation within the forest cultivation zone," International Journal of Scientific \& Technology Research, vol. 6, pp. 393-399, 2017.

[46] M. Haigh, M. Desai, M. Cullis et al., "Composted municipal green waste enhances tree success in opencast coal land reclamation in Wales," Air, Soil and Water Research, vol. 12, pp. 1-10, 2019.

[47] D. Martínez-Fernández, E. Arco-Lázaro, M. P. Bernal, and R. Clemente, "Comparison of compost and humic fertiliser effects on growth and trace elements accumulation of native plant species in a mine soil phytorestoration experiment," Ecological Engineering, vol. 73, pp. 588-597, 2014.

[48] A. Oyebamiji, A. Amanambu, T. Zafar, A. J. Adewumi, and D. S. Akinyemi, "Expected of active mining on the distribution of heavy metals in soils around Iludun-Oro and its environs, Southwestern Nigeria," Congent Environmental Science, vol. 4, no. 1, Article ID 1495046, 2018.

[49] S. Tandy, J. Healey, M. A. Nason, and J. C. Williamson, "Remediating of metal polluted mine soil with compost: cocomposting versus incorporation," Environmental Pollution, vol. 157 , no. 2, pp. 690-697, 2008.

[50] J. R. Miller, J. P. Gannon, and K. Corcoran, "Concentrations, mobility, and potential ecological risks of selected metals within compost amended, reclaimed coal mine soils, tropical South Sumatra, Indonesia," AIMS Environmental Science, vol. 6, no. 4, pp. 298-325, 2019.

[51] R. Jacoby, M. Peukert, A. Succurro, A. Koprivova, and S. Kopriva, "The role of soil microorganisms in plant mineral nutrition-current knowledge and future directions," Frontiers in Plant Science, vol. 8, p. 1617, 2017.

[52] D. Wulandari, Saridi, W. Cheng, and K. Tawaraya, "Arbuscular mycorrhizal fungal inoculation improves Albizia saman and Paraserianthes falcataria growth in post-opencast coal mine field in East Kalimantan, Indonesia," Forest Ecology and Management, vol. 376, pp. 67-73, 2016.

[53] M. M. Fernandes, R. F. Pereira, F. M. Matos da Silva et al., "Development of Anadenanthera colubrine seedlings subjected to different doses of coconut powder and arbuscular mychorrhizal for rehabilitation of mining areas," International Journal of Plant and Soil Science, vol. 31, no. 6, pp. 1-6, 2019.

[54] C. Agus, E. Primananda, E. Faridah, D. Wulandari, and T. Lestari, "Role of arbuscular mycorrhizal fungi and Pongamia pinnata for revegetation of tropical open-pit coal mining soils," International Journal of Environmental Science and Technology, vol. 16, no. 7, pp. 3365-3374, 2018.

[55] D. Gao, X. Wang, S. Fu, and J. Zhao, "Legume plants enhance the resistance of soil to ecosystem disturbance," Frontiers in Plant Science, vol. 8, p. 01295, 2017.

[56] F. Stagnari, A. Maggio, A. Galieni, and M. Pisante, "Multiple benefits of legumes for agriculture sustainability: an overview," Chemical and Biological Technologies in Agriculture, vol. 4, no. 2, 2017. 